\title{
The Effect of Ethanolic Extract of Olive (Olea europea L.) Leaves on BALB/c Mice
}

\author{
Nurul Hiedayati, Nurlaely M. Rachmawati, Riva Auda, M. Iqbal Dzaki, Nihayatul Kamila, Aris Purnomo \\ Medical Study Program \\ Faculty of Medicine and Health Sciences \\ Syarif Hidayatullah State Islam University \\ Jakarta, Indonesia \\ nurul.hiedayati@uinjkt.ac.id
}

\begin{abstract}
Olives has been mentioned in holly books, Quran and Bible, as medicinal and good nutritional food. People using it as a herbal medicine for centuries. However, we concern about its toxicity to some organs tissues. In this study, we observed histopathological changes on stomach, liver and kidney tissues of BALB/c mice after administrated with ethanolic extract of olive leaves (OLE). Male BALB/c mice were divided into three groups. Each group subsequently orally administrated with phosphate buffer saline (group-I), or OLE (100 mg/kg (group-II); $200 \mathrm{mg} / \mathrm{kg}$ (group-III)) for ten consecutive days before necropsy. Mice were sacrificed next day and stomach, liver and kidney tissue were observed for histopathological changes using hematoxyline-eosin. Observation using Corel Photo PX7. Stomach mucosal epithelial damage were $1.9 \%, 3.2 \%$ and $1.7 \%$, hepatocyte damages were $40 \%, 38.1 \%, 63,1 \%$, Glomerular atrophy were $11.5 \%, 9.9 \%$ and $11,5 \%$, kidney tissue bleeding area were $3.7 \%, 3.1 \%, 4.1 \%$ in group-I, -II and -III respectively. Ethanolic extract of local olive leaves have mucoprotective activity on stomach tissues, but at 200 $\mathrm{mg} / \mathrm{kg}$ have a toxic effect on mice liver and kidney tissues.
\end{abstract}

Keywords-- Acute toxicity; olive leaves

\section{INTRODUCTION}

Herbal medicine has been used for many centuries in the Indonesian community to maintain good health and to treat several diseases. Although conventional medicine is becoming increasingly important in Indonesia, herbal medicine is still very popular in rural as well as in urban areas. One of the popular herbal medicine is olive (Olea europaea L) which has been closely associated with human religious, sociocultural, medicinal, and nutritional needs [1]. Olive is one of the plants comes from Mediterranean and known to be rich source of bioactive compounds that have significant role in curing of various diseases. The benefits of this plant is obtained from secondary metabolite, phenolic and oleuropein compounds $[2,3]$. Both of these compounds are not only found in olives but also found in plant organs, such as on leaves, stems or olive seeds. The highest oleuropein is not only in olives, but also on olive leaves $[3,4]$.

Previous study showed several Oleuropein benefits, such as a potent antioxidant with anti-inflammatory properties $[5,6]$, prevent and treat cancer [7,5], hypoglycemic agent [8]
Drugs, both synthetic and herbal will go through various stages that include 4 processes, namely absorption, distribution, metabolism and excretion [9]. Likewise olives as herbal medicine will pass through all four processes. All chemicals, including herbs on the amount of concentration and frequency of certain exposure can have the potential to cause cell injury. Such cell injury may manifest by changes in the number, size, function, or phenotype of cells exposed to toxic substances [10]. When a substance has reached toxic levels, all exposed cells, including stomach mucous, cells in the liver organ, and kidney glomerulus will respond. The most common pathogenesis of toxic effects of herbs is the occurrence of irritation or inflammation of the gastrointestinal mucosa[9] .Drug-induced liver injury (DILI) is divided into 3 categories, namely hepatocyte damage, vascular disorders, hyperplasia, and neoplasia [11]. A study by R. Arantes Rodrigues et al [12] suggests that in the administration of olive leaf extract at concentrations of $0.25 \%, 0.50 \%$, and $0.75 \%$ obtained a description of bile duct hyperplasia, cholestasis, hepatocyte necrosis, and inflammatory cell infiltration. In addition, in the two highest doses olive may result in hepatic fibrosis. Omer [13] reported that the use of high concentrations of olive leaf extract can provide nephrotoxic and hepatotoxic side effects.

Although many studies report on the benefits of olive leaf extract (OLE), only few studies have reported on its. This study was undertaken to evaluate the possible histopathological of stomach, liver and kidney leaves changes which may results from intake of olive leaves extract with dose variation of 100 $\mathrm{mg} / \mathrm{kg}$ body weight (BW) and $200 \mathrm{mg} / \mathrm{kgBW}$ in mice BALB/c mice which is used as natural therapy

\section{METHODS}

\section{A. Olive leaves extract}

Fresh green olive leaves were obtained from local olive nurseries at Depok, West Java. The leaves were identified and confirmed by Center for Plant Conservation Botanic Gardens, Indonesian Institute of Sciences. Two $\mathrm{kg}$ fresh olive leaves extracted with $96 \%$ ethanol at Research Institute of Spices and Medicinal Plants, Bogor Agricultural University by maceration 
extraction techniques. The extract was concentrated and get a thick brown semisolid paste (yield 26.07\%).

\section{B. Animals}

Fifteen healthy male BALB/c mice were obtained from Department of Pathology of Bogor Agricultural University. The average age of the mice was approximately 5-6 weeks (25-30 g). The mice were acclimatized to laboratory conditions for 7 days prior to treatment and observed for any sign of illness. Five mice were housed in single cage on wood shaving's bedding. The animal room was maintained at $24-25^{\circ} \mathrm{C}$ and $50-60 \%$ relative humidity and a $12 \mathrm{~h}$ light/dark cycle throughout experiment. All animas were supplied with commercial diet and tap water ad libitum throughout the acclimation and testing periods.

\section{Study design}

Briefly, 15 mice were randomized divided into three groups $(\mathrm{n}=5)$. Subsequently orally given $100 \mu \mathrm{l}$ PBS (group-I), 100 $\mathrm{mg} / \mathrm{kg}$ or $200 \mathrm{mg} / \mathrm{kg}$ of OLE (group-II or group -III) for seven consecutive days. Mice were deprived of food but free to drink water $24 \mathrm{~h}$ before sacrificed.

\section{Tissue sample collection}

Mice were anesthetized and sacrificed by inhaled with ether $24 \mathrm{~h}$ after last treatment. Surgical process performed on the abdominothoracal. Stomach, liver and kidney were immediately removed. These organ tissue were fixed into $10 \%$ buffer formalin for $24 \mathrm{~h}$.

\section{E. Histophatological analysis}

Organ tissue slides were made in Department of Histology, University of Indonesia. It stained with hematoxyline and eosin (H\&E) for light microscopic qualitative examination. Observation and photograph documentation by Olympus BX41 microscope and Olympus DP2-BSW software.

\section{F. Analysis Data}

Result are expressed as mean \pm SD. The result were analyzed by one way ANOVA to determine the significant differences between means. A $\mathrm{P}<0.05$ was considered to be statistically significant

\section{RESULTS AND DISCUSSION}

\section{A. Histopatologycal features}

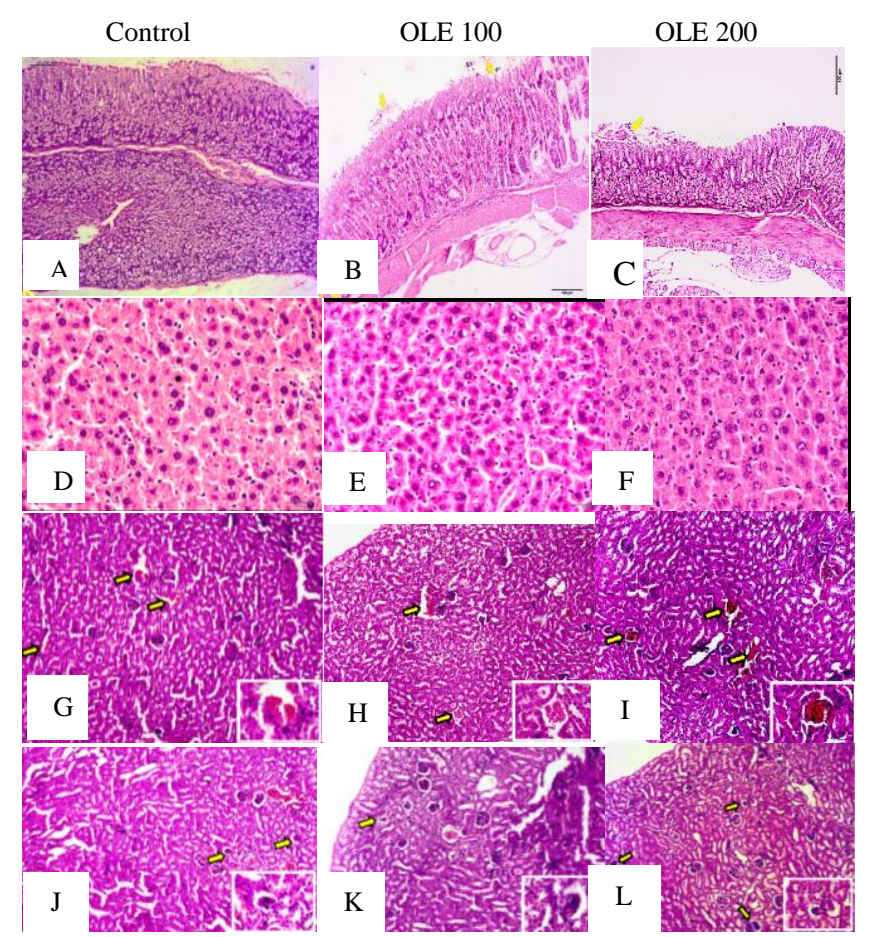

Fig. 1. A, B and C are the stomach images of groups I, II and III, arrows indicate mucosa damage. I. D, E, F are group I, II and III liver images, arrows indicate abnormal hepatocyte cells. G, H, I is a picture of kidney tissue groups I, II and III, arrows indicate the area of bleeding. J, K, L is a picture of kidney tissue of groups I, II and II, arrows indicating glomerular atrophy.

\section{B. Stomach}

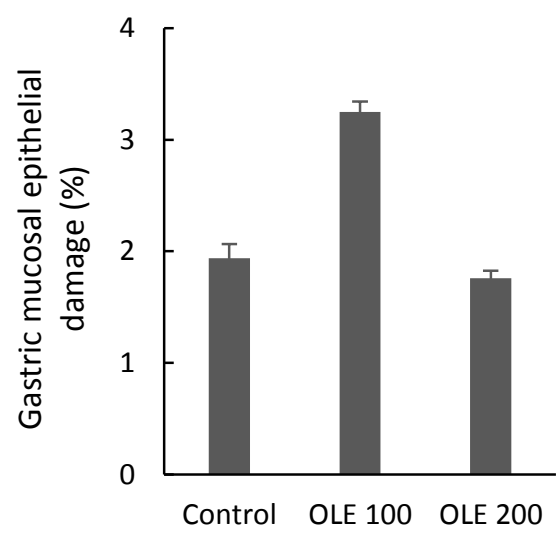

Fig. 2. Effect of OLE in rat gastric mucosal epithelial damage.

Statistical analysis of histopathologic features of three organ tissues showed different responses to the olive leaf extract intake. The damage to the epithelial layer of the gastric mucosa is determined by the formula (1):

$$
\left[\frac{\text { Damage area }}{\text { Total area of stomach mucous }}\right] \times 100 \%
$$


In Fig. 2 showed that the groups II and III did not differ significantly with group I. Group III showed better results from group I. This is probably due to the gastroprotective effect of olive leaf extract, which contains oleuropein and hydroxityrosol [14]. This results means that the administration of olive leaf extract does not result in toxic effects on the gastric tissue of $\mathrm{BALB} / \mathrm{c}$ mice

\section{Liver}
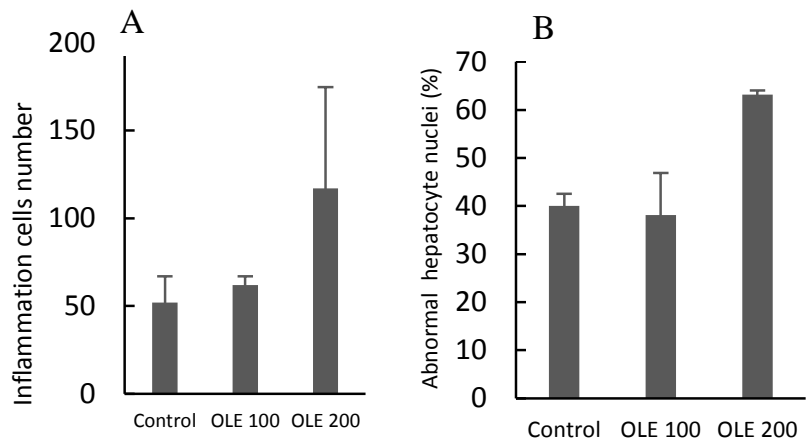

Fig. 3. Effect of OLE in rat hepatocyte. (A) Inflammation cells number, (B) Abnormal hepatocyte nuclei.

In liver tissue, the parameter used to measure the extent of damage is the number of hepatocyte cells with abnormal nuclei. The damage is determined by the formula (2):

$$
\left[\frac{\text { Number of hepatocyte cells with abnormal nucleus }}{\text { Total hepatocyte cells number }}\right] \times 100 \%
$$

Increasing the percentage of abnormal hepatocyte nuclei may indicate liver toxicity. Histologically, cell structure abnormalities can be assessed from the nucleus, cytoplasm, or cell membrane. The size change nucleus becomes small or bulging, the color is not purple with $\mathrm{H} \& \mathrm{E}$ staining; non homogeneous cytoplasm; and non-polyhedral cells describe the features of tissue necrosis [10].

Group III when compared with group I and II showed higher abnormal hepatocyte percentage. This is due to the larger dose given. Another reason that may affect is the type of olive extract used. With the use of crude extracts, without the distillation of stratum to take active substances such as oleuropein and hydroksitirosol, there are other active substances that can affect the liver work [15].

Group II showed lower abnormal hepatocyte percentage than the controls, while the higher olive-dose group showed an increased percentage of abnormality. This suggests that the effect of olive leaf extract on the liver is dosage dependent, in the certain doses can cause hepatotoxicity. R. ArantesRodrigues (2011) reported that changes in hepatic morphology, necrosis, and inflammatory cell infiltration given olive leaf extract for 14 weeks were associated with a decrease in cell energy as a manifestation of mitochondrial malfunctions. Mitochondria, under certain conditions may be the source of ROS against cells [12].
D. Kidney

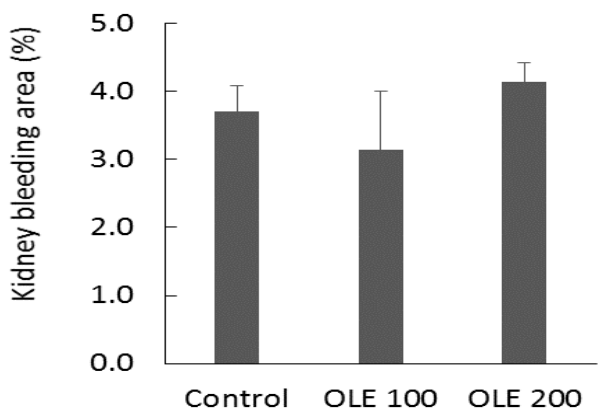

Fig. 4. Effect of OLE in rat kidney

The kidney is highly susceptible to toxicants for two reasons. A high volume of blood flows through it and it filters large amounts of toxins which can concentrate in the kidney tubules. It can result in systemic toxicity causing: decreased ability to excrete body wastes, inability to maintain body fluid and electrolyte balance and decreased synthesis of essential hormones [16]. Additionally, kidneys are highly vulnerable to damage caused by reactive oxygen species (ROSs), likely due to crude extract.

In kidney tissue, the parameters used to measure the extent of damage are the number of bleeding areas.

The damage is measured by the formula (3):

$$
\left[\frac{\text { Total area of bleeding }}{\text { total number of total area }}\right] \times 100 \%
$$

From the results it is seen that group III has a wide area bleeding most of all groups. This indicates that the higher the granting dose will increase the occurrence of side effects (dose dependent) in the form expansion of bleeding areas. These results are consistent with the Omer (2012) study that the higher concentration of olive leaf extract will increase the area bleeding [13].

\section{CONCLUSION}

Ethanolic extract of local olive leaves have mucoprotective activity on stomach tissues, but at $200 \mathrm{mg} / \mathrm{kg}$ have a toxic effect on mice liver and kidney tissues.

\section{ACKNOWLEDGMENT}

This work supported by research grant from LPPM UIN Syarif Hidayatullah and Ministry of Religion Affairs on 2015.

\section{REFERENCES}

[1] B. Raina, "Olives", Encyclopedia of food sciences and nutrition, vol. 2, pp. $4260-4267,2003$.

[2] De la Torre-Carbot K, O. Jauregui, E.Gimeno, AI. Castellote, RM. Lamuela-Raventós, MC. López-Sabater, "Characterization and quantification of phenolic compounds in olive oils by solid-phase extraction, HPLC-DAD, and HPLC-MS/MS”. J Agric Food Chem., vol. 1;53(11), pp. 4331-40, Jun 2005. 
[3] S. Silva, L. Gomes, F. Leitão, A.V Coelho, \& L. Vilas Boas, "Phenolic compounds and antioxidant activity of Oleaeuropaea L. fruit and leaves". Food Science and Technology International, vol. 12(5), pp. 385-396, 2006.

[4] D. Ryan, M. Antolovich, P. Prenzler, K. Robards, Lavee, "S.Biotransformations of phenolic compounds in Olea europaea L. Sci Hort", vol. 92, pp. 147-317, 2002.

[5] NK. Andrikopoulos, S. Antonopoulou, AC. Kaliora, "Oleuropein inhibits ldl oxidation induced by cooking oil frying by-products and platelet aggregation induced by platelet-activating factor". LWT Food Sci. Technol, vol. 35, pp. 479-484, 2002.

[6] F. Visioli, S. Bellosta, C. Galli, Oleuropein, the bitter principles of olives, enhances nitric oxide production by mouse macrophages.Life Sciences, vol. 62(6), pp. 541-546, $1998 .$.

[7] RW. Owen, R Haubner, G Würtele, WE. Hull, B. Spiegelhalder and H. Bartsch, "Olives and olive oil in cancer prevention, European Journal of Cancer Prevention", vol. 13, pp. 319-326, 2004.

[8] M. Eddouks, "Efficacy and Safety of Olive in the Management of Hyperglycemia", Pharmaceut Reg Affairs, vol. 4:1, 2014.

[9] G. Bertram, Katzung, J. Anthony, Trevor, "Basic \& Clinical Pharmacology", 13th ed.

[10] Robbins Basic Pathology, 10th Edition

[11] PO. Sharma, A. Singh, TK. Bhat, 'Clinical biochemistry of hepatotoxicity', J Clin Toxicol, vol. 4(1), pp. 1-19, 2011.

[12] R. Arantes-Rodrigues, A. Henriques, MJ. Pires, B. Colaço, AM. Calado, P. Rema, et al. "High doses of olive leaf extract induce liver changes in mice", Food Chem Toxicol, vol. 49(9), pp. 1989-97, 2011.

[13] Omer, A. Sawsan, et al., "Toxicity of Olive Leaves (Olea europea L,) in wistar albino rats", Asian Journal of Animal and Veterinary Advances, vol. 7(11), pp. 1175-1182, 2012.

[14] AH. Hashmi, A. Khan, M. Hanif, U. Farooq, S. Perveen, "Traditional Uses, Phytochemistry, and Pharmacology of Olea europaea (Olive). Evidence-Based Complementary and Alternative Medicine”. pp. 1-2,. 2015.

[15] E. Waterman, B. Lockwood, "Active components and clinical applications of olive oil”. Altern Med Rev., vol. 12(4), pp. 331-42, 2007.

[16] T. Oduola, I. Bello, G. Adeosun, AW. Ademosun, G. Raheem, and G. Avwioro, "Hepatotoxicity and nephrotoxicity evaluation in Wistar albino rats exposed to Morinda lucida leaf extract". N Am J Med Sci, vol. 2(5): pp. 230-233, May 2010. 